\title{
Risk Factors for Diarrhea Cases in Communities Living Along Deli River, North Sumatera
}

\author{
Elvita Susanti
}

Masters Program in Public Health, Universitas Sumatera Utara

\begin{abstract}
Background: Diarrhea disease is the second leading cause of death in children under five years old, and is responsible for killing around 525,000 children every year. Interventions to prevent diarrhea, including safe drinking-water, use of improved sanitation and hand washing with soap can reduce disease risk. This study aimed to investigate risk factors of diarrhea among communities living along Deli river, North Sumatera.

Subjects and Method: This was a cross-sectional study conducted in communities living along Deli river, North Sumatera. A sample of 96 study subjects was selected for this study. The dependent variable was diarrhea. The independent variables were use of toilet, clean water, hand wash, processing of waste, human excreta. The data were collected by questionnaire and analyzed by a multiple logistic regression.

Results: The risk of diarrhea increased with lack of toilet use $(\mathrm{OR}=1.67 ; 95 \% \mathrm{CI}=0.99$ to $2.79 ; \mathrm{p}=$ $0.040)$, poor use of clean water $(\mathrm{OR}=1.66 ; 95 \% \mathrm{CI}=1.02$ to $2.70 ; \mathrm{p}=0.035)$, hand washing without soap $(\mathrm{OR}=1.74 ; 95 \% \mathrm{CI}=1.12$ to $2.68 ; \mathrm{p}=0.002)$, poor garbage management $(\mathrm{OR}=2.50 ; 95 \% \mathrm{CI}=$ 1.33 to $4.89 ; \mathrm{p}=0.001)$, and improper human excreta disposal $(\mathrm{OR}=1.64 ; 95 \% \mathrm{CI}=1.04$ to $2.60 ; \mathrm{p}=$ 0.032).

Conclusion: The risk of diarrhea increases with lack of toilet use, lack of clean water, hand washing without soap, poor waste management, and improper human excreta disposal.
\end{abstract}

Keywords: diarrhea, personal hygiene, sanitation

Correspondence:

Elvita Susanti. Masters Program in Public Health, Universitas Sumatera Utara, Jl. Universitas No. 21, Medan, North Sumatera. Email: elvitasusantiskm@gmail.com. Mobile: o81375520310, o8116005324.

\section{BACKGROUND}

Diarrhea is still one of the main causes of illness and death. According to WHO (World Health Organization) data (2013), there are around 4 billion cases of diarrheal disease occurring every year in the world. WHO reports that the main causes of death in infants are diarrhea (post neonatal) 14\% and pneumonia (post neonatal) 14\% then malaria 8\%, non-communicable diseases (post neonatal) 4\% injuri (post neonatal) $3 \%$, HIV/AIDS $2 \%$, Measles $1 \%$, and others $13 \%$, and infant mortality $<1$ month (newborns death) $41 \%$. Diarrhea is still a public health problem in developing countries such as Indonesia, because the morbidity and mortality are still high. In 2013, there were 8 outbreaks spread across 6 provinces, 8 districts with a total of 646 people with 7 deaths (Case Fatality Rate/CFR= 1.08\%). Whereas in 2014, there were 6 outbreaks of diarrhea in 5 provinces, 6 regencies or cities, with 2,549 people with 29 deaths $(\mathrm{CFR}=1.14-\%)$. One of the provinces that experienced epidemic was Lampung Province (Kementerian Kesehatan RI, 2015).

Blum (1974) states that factors that can directly or indirectly causes of diarrhea, consisting of agent, host, environment factors. The most dominant environmental factors are facilities for clean water supply 
Journal of Epidemiology and Public Health (2019), 4(1): 47-54

https://doi.org/10.26911/jepublichealth.2019.04.01.06

and fecal disposal, these two factors will interact together with human behavior. If the environmental factors are unhealthy because they are contaminated with diarrhea and accumulate with unhealthy human behavior, transmission of diarrhea can easily occur (MOH, 2005).

Profile of the Medan City Health Office, in 2015, state that the number of diarrhea morbidity in Medan City was 22,932 people. The number decreased from 2014 ammounting to 25,575 people. Despite a decrease in diarrhea, the morbidity rate is still relatively high due to factors such as sanitation and many other factors. Diarrhea is ranked fifth of the 10 biggest diseases in Medan City Health Center.

Report of the Wampu Sei Ular Watershed Management Agency (2005) shows that forest cover in the Deli Watershed is only $7.5 \%$ of the watershed area and this is far from ideal conditions. In addition, in terms of the quality of the threat of water pollution comes from domestic waste and industrial waste. Medan is among the ten heavily polluted cities in Indonesia (Analisa, 2003).

Human factors that use the banks of the Deli river to establish settlements and waste disposal have narrowed the river channel. Blockage of waste in the riol grooves and creeks has worsened the environment. In addition, domestic waste water disposal facilities have conditions that do not meet health requirements, where it can be seen that the household waste water produced is directly discharged into the river. This condition is clearly very influential on the quality of clean water sources because it can contain chemical compounds and harmful microorganisms (Angelin et al., 2012).

The initial survey and observation were carried out by researchers on January 19, 2018 at two points or locations of the
Deli watershed, namely Medan Marelan (point 1), Medan Maimun (point 2). In these two locations, the majority of the population still used river water, for washing, bathing and latrines, if seen the Deli river looks cloudy, yellowish brown and visible domestic industrial waste, while in the lower reaches of the river, most people still use Deli river water for Mandi Cuci Kakus (MCK). In addition, domestic waste water disposal facilities have conditions that do not meet health requirements where it can be seen that the household waste water produced is immediately discharged into the river body. Data from diarrhea patients in Medan Maimun Public Health Center show that there were 390 people diarrhea and 1,094 from Medan Marelan Health Center (Dinas Kesehatan Kota Medan, 2017).

\section{SUBJECTS AND METHOD}

\section{Study Design}

This was an analytic observational study with a cross sectional design. The study was carried out in communites living along Deli River, North Sumatera.

\section{Population and Samples}

The target population in this study was todllers in communites living along Deli River. A sample of 96 study subjects was selected for this study by consecutive sampling.

\section{Study Variables}

The dependent variable was diarrhea. The independent variables were The independent variables were use of toilet, clean water, hand wash, processing of waste, human excreta.

\section{Data Analysis}

Data on diarrhea was collected by medical record. The other variables were measured by questionnaire. The data were analyzed by a multiple logistic regression. 


\section{RESULTS}

Based on the results of the laboratory examination, it was found that the middle Coolifecal upstream level was 1,700 MPN/ $100 \mathrm{ml}$ and at right, middle, and left downstream the level was 9,200 MPN/

Table 1. Bivariate analysis 10oml, this meant that this figure had exceeded the quality standard (1,00o MPN/ 10oml) based on the Regulation Government 81 years in 2001 concerning Water Quality Management and Water Pollution Control, Class II.

\begin{tabular}{|c|c|c|c|c|c|c|c|c|}
\hline \multirow{2}{*}{$\begin{array}{c}\text { Independent } \\
\text { Variables }\end{array}$} & \multicolumn{2}{|c|}{ Diarrhea } & \multicolumn{2}{|c|}{ No Diarrhea } & \multirow{2}{*}{ OR } & \multicolumn{2}{|c|}{$95 \% \mathrm{CI}$} & \multirow[b]{2}{*}{$\mathbf{p}$} \\
\hline & $\mathbf{n}$ & $\%$ & $\mathbf{n}$ & $\%$ & & $\begin{array}{l}\text { Lower } \\
\text { Limit }\end{array}$ & $\begin{array}{l}\text { Upper } \\
\text { Limit }\end{array}$ & \\
\hline \multicolumn{9}{|l|}{ Age } \\
\hline 17-35 years & 31 & 44.9 & 38 & 55.1 & 1.10 & 0.65 & 1.86 & 0.710 \\
\hline$<17,>35$ years & 11 & 40.7 & 16 & 59.3 & & & & \\
\hline \multicolumn{9}{|l|}{ Gender } \\
\hline Male & 23 & 39.0 & 36 & 61.0 & 0.76 & 0.49 & 1.19 & 0.234 \\
\hline Female & 19 & 51.4 & 18 & 48.6 & & & & \\
\hline \multicolumn{9}{|l|}{ Education } \\
\hline Low & 23 & 39.0 & 36 & 61.0 & 0.76 & 0.49 & 1.19 & 0.234 \\
\hline High & 19 & 51.4 & 18 & 48.6 & & & & \\
\hline \multicolumn{9}{|l|}{ Occupation } \\
\hline Not working & 38 & 43.7 & 49 & 56.3 & 0.98 & 0.46 & 2.12 & 0.965 \\
\hline Working & 4 & 44.4 & 5 & 56.6 & & & & \\
\hline \multicolumn{9}{|l|}{ Income } \\
\hline$<\operatorname{Rp} 3,484,000$ & 35 & $45 \cdot 5$ & 42 & 54.5 & 1.23 & 0.65 & 2.33 & 0.498 \\
\hline$\geq \operatorname{Rp} 3,484,000$ & 7 & 36.8 & 12 & 63.2 & & & & \\
\hline \multicolumn{9}{|l|}{ Use of latrines } \\
\hline Poor & 20 & 60.6 & 13 & 39.4 & 1.67 & 0.99 & 2.79 & 0.040 \\
\hline Good & 22 & 34.9 & 41 & 65.1 & & & & \\
\hline \multicolumn{9}{|l|}{ Use of clean water } \\
\hline Poor & 27 & 54.0 & 23 & 46.0 & 1.66 & 1.02 & 2.70 & 0.035 \\
\hline Good & 15 & 32.6 & 31 & 67.4 & & & & \\
\hline \multicolumn{9}{|l|}{ Washing hands } \\
\hline Without soap & 20 & 60.6 & 13 & 39.4 & 1.74 & 1.12 & 2.68 & 0.016 \\
\hline With soap & 22 & 34.9 & 41 & 65.1 & & & & \\
\hline \multicolumn{9}{|c|}{ Waste management } \\
\hline Poor & 34 & 56.7 & 26 & $43 \cdot 3$ & 2.50 & 1.33 & 4.89 & 0.001 \\
\hline Good & 8 & 22.2 & 28 & 77.8 & & & & \\
\hline \multicolumn{9}{|l|}{ Fecal disposal } \\
\hline Poor & 24 & 55.8 & 19 & 44.2 & 1.64 & 1.04 & 2.60 & 0.032 \\
\hline Good & 18 & 34.0 & 35 & 66.0 & & & & \\
\hline \multicolumn{9}{|l|}{ Waste disposal } \\
\hline Poor & 12 & 36.4 & 21 & 63.6 & 0.76 & 0.45 & 1.29 & 0.291 \\
\hline Good & 30 & 47.6 & 33 & 52.4 & & & & \\
\hline
\end{tabular}


Journal of Epidemiology and Public Health (2019), 4(1): 47-54

https://doi.org/10.26911/jepublichealth.2019.04.01.06

In Medan Marelan Subdistrict, the condition of river water is more concerning than the condition of Medan Maimun District. Toddlers who experienced diarrhea in the last month at Terjun health center were 22 (45.8\%), while toddlers who experienced diarrhea at the Kp. Aur health center were 20 (41.7\%).

\section{Bivariate Analysis}

Table 1 shows the results of bivariate analysis. Table 1 shows that there were association between poor use of latrines, poor use of clean water, washing had without soap, poor waste management, poor fecal disposal, and the risk of diarrhea. Poor use of latrines $(\mathrm{OR}=1.67 ; 95 \% \mathrm{CI}=0.99$ to 2.79 ; $\mathrm{p}=0.040)$, poor use of clean water $(\mathrm{OR}=$ $1.66 ; 95 \% \mathrm{CI}=1.02$ to $2.70 ; \mathrm{p}=0.035)$, washing had without soap $(\mathrm{OR}=1.74 ; 95 \%$ $\mathrm{CI}=1.12$ to $2.68 ; \mathrm{p}=0.016$ ), poor waste management $(\mathrm{OR}=2.50 ; 95 \% \mathrm{CI}=1.33$ to 4.89; $\mathrm{p}=0.001$ ), and poor fecal disposal $(\mathrm{OR}=1.64 ; 95 \% \mathrm{CI}=1.04$ to $2.60 ; \mathrm{p}=$ $0.032)$ increased the risk of diarrhea.

Table 2. The results of multiple logistic regression

\begin{tabular}{lccc}
\hline \multicolumn{1}{c}{ Independent Variables } & OR & $\mathbf{9 5 \%}$ CI & p \\
\hline Hand washing without soap & 3.19 & 0.13 to 8.38 & 0.018 \\
Poor use of clean water & 2.78 & 1.11 to 7.00 & 0.030 \\
Poor waste management & 4.92 & 1.81 to 13.33 & 0.002 \\
Constants & 0.10 & & 0.003 \\
\hline
\end{tabular}

\section{Multivariate Analysis}

Table 1 shows the results of multiple logistic regression. Table 1 shows that there were positive association and statistically significant between poor use of clean water, washing had without soap, poor waste management, and the risk of diarrhea. Poor use of clean water $(\mathrm{OR}=2.78 ; 95 \% \mathrm{CI}=1.11$ to 7.00; $\mathrm{p}=0.030$ ), washing had without soap $(\mathrm{OR}=3.19 ; 95 \% \mathrm{CI}=0.13$ to $8.38 ; \mathrm{p}=$ o.018), and poor waste management ( $\mathrm{OR}=$ 4.92; $95 \% \mathrm{CI}=1.81$ to $13.3 ; \mathrm{p}=0.002)$ increased the risk of diarrhea.

\section{DISCUSSIONS}

\section{The Relationship between Healthy Behavior Factor and the Incidence of Diarrhea among Toddlers}

The result of observations on the respondents showed that there were some respondents who still did not have their own toilet, still using public latrines, still used toilet without septic tanks that flowed directly into the river, mud toilet and even emergency toilet on the riverbank, even behind the house by using soil to cover the feces. Some uncovered and unclean toilets were found. Non-sanitary conditions could cause the spread of diarrhea, the human excreta which were not disposed in the right place would allow flies and then seize the family's food source, as well as feces which were disposed carelessly that can pollute the sources of clean water.

The similar results can also be found in a study done by Sunarti (2015) which stated that there was a relationship between the use of toilet and the incidence of diarrhea among toddlers in Padang Sidempuan $(\mathrm{OR}=4.00 ; 95 \% \mathrm{CI}=1.50$ to 10.66; $p=0.004)$. The excreta which were carelessly disposed was a risk factor for diarrhea in toddlers when doing a direct contact with hands when children play at the ground in the yard or behind the house or indirectly through vectors such as flies that land on feces and it was transmitted through food. Lack of attention to human excreta management accompanied by rapid population growth would accelerate the spread of fecal-borne diseases such as 
diarrhea which was one of the environmental-based infectious diseases as a risk factor for diarrhea.

Based on the observations, there were a lot of community who behave badly and did not pay attention to the clean water which would be used as drinking water. Based on physical observation, the water still has a taste and it was not clear, and people did not pay much attention to drinking water reservoirs.

This was in line with a study of Hannif et.al (2011) which showed that clean water source which were at high risk was one of the factors that affected the occurrence of acute diarrhea in toddlers. Children with families who did not use clean water sources were 2.65 times more likely to experience diarrhea.

According to Suyono (2013), water was a vital element for the lives of creatures on the earth, water was used for various purposes, including drinking, bathing, washing the household appliances, washing clothes, and cooking which were all basic necessities. Water consumed by humans must be clean, free of chemical, biological, and bacteriological pollutants.

One of the efforts to reduce the risk of diarrheal diseases was the procurement and improvement of the clean water facilities to avoid the contamination of disease-causing agents. In addition, the community must boil the drinking water first to turn off the causative agent in the clean water (Madhi et al., 2010; Stefano et al., 2011).

The results of observation showed that there were many people who did not provide water flow and soap to wash their hands. The researcher assumed that there were a lot of mothers who did not know the right time to wash their hands by using soap, many of them refused to wash their hands by using soap because they did not know the benefits of preventing diarrhea in children. The behavior of hand washing by using soap was a maternal hygiene behavior, good personal hyegine could prevent diarrhea. According to Kementerian Kesehatan RI (2011), if it was examined from the aspect of public health especially the spread of transmitted diseases pattern, there were huge number of diseases which can be prevented through habits or hygienic behavior by washing hands with soap, such as diarrhea, abdominal typhoid, helminthiasis, avian influenza, and even swine influenza diseases which were horrendous in the world.

Hand washing behavior especially hand washing with soap was still an important target in health promotion, especially regarding the clean and healthy behavior. This was because the behavior was still low, there were only $12 \%$ of community who used the soap to wash their hands after defecating, there were only $9 \%$ of mothers who used the soap to wash their hands after cleaning their babies' feces, there were only $7 \%$ community who used the soap to wash their hands before feeding their babies, there were only $14 \%$ of community who used soap to wash their hands before eating. With proper hand wash behavior which was by using soap and clean water, it could reduce the incidence of diarrhea.

An important habit which related to personal hygiene in the transmission of diarrheal germs was hand washing. Washing the hands with soap, especially after defecating, cleaning children's feces, before preparing the food, before feeding a child, and before eating has an impact on the incidence of diarrhea, and it could reduce the incidence of diarrhea by $47 \%$. Study by Departement Technique Action Contre Ia FAIM Fr stated that there were some diseases which can be prevented by mantaining the food, which were diarrhea, 
Journal of Epidemiology and Public Health (2019), 4(1): 47-54

https://doi.org/10.26911/jepublichealth.2019.04.01.06

typhoid, parathypoid, and hepatitis A. Another study showed that washing all the food ingredients before cooking, cleaning all the cooking ware by using soap and clean water, and covering the food could reduce the incidence of diarrhea (UNICEF Liberia, 2012)

\section{The Relationship between Environ- mental Factor and the Incidence of Diarrhea among Toddlers}

Waste that was not managed properly could lead to vector misses, such as the habit of piling up trash in the backyard, burning or throwing it away after a few days, placing garbage in an uncovered bucket or trash can, so that it caused odors and inviting the flies as germ carriers that could pollute the food and drinks. Similar result also showed by a study done by Sunarti (2015) which stated that there was a relationship between waste processing and the incidence of diarrhea among toddlers in Padangsidempuan $(\mathrm{OR}=4.64 ; \mathrm{p}=0.107)$.

A study done by Sabariah (2014) stated that waste management was an influential factor on the incidence of diarrhea among toddlers in Sei Sekambing C-II subdistrict, Medan Helvetia (OR= 2.67; $\mathrm{p}=$ o.018).

According to Sutomo (2013), solid waste that was not managed properly would be a problem for public health. This could happen because waste could provide a place for disease vectors. Solid waste which contained flies' favourite food could invite the flies and they even lay eggs in a garbage pile. Dirty solid waste could also be a nest of cockroaches which could expand the sources of diarrhea disease.

Family toilets were the buildings that were used to feces disposal for families. Clean and healthy toiletes must have some requirements, among others: did not pollute the source of drinking water, the feces cannot be touched by insects or rats, so that the feces must be closed tightly, for example by using a tight hole cover, urine (cleaning water and flushing), did not pollute the surrounding land, therefore, the toilet floor must be at least $1 \times 1$ meters wide and made quite sloping or tilted towards the squat hole, easy to clean and safe to use, equipped with a protective wall and roof where the walls were waterproof and have a light color, sufficient lighting, waterproof floors, sufficient room sizes, good ventilation, and the water and cleaning equipment were provided.

The result of a study on the quality of bacteriological clean water in Jakarta showed that $24 \%$ of surface water were contaminated by fecal coliform, and only $3 \%$ of polluted WSC water (Hannif et al., 2011). Based on the results of observation, it was not only the community who disposed the feces into the river, but also the home industry and even bigger company which disposed their waste to Deli River, Medan. A closed sewerage in the sense that it can actually be opened to be cleaned could cause a vector nest. Waste water can contained diseases which could lead to waterborne diseases. Waste that was not managed properly could become a source of disease vectors such as mosquitoes, flies, cockroaches, and others (Mulia, 2005). Unhealthy waste water disposal could lead to pollution on the soil surface and water sources.

Toddlers were an age group that was susceptible to diseases because the immune system was still weak so it was susceptible to bacterial, viruses or parasitic. Generally, the highest incidence of diarrhea occurred in first and second year of life and it decreased with age. Every year, there were 2,5 billion of diarrhea cases which occurred in toddlers (UNICEF and WHO, 2009).

Waste management was a systematic, comprehensive and continuous activities 
that include waste reduction and handling (Government Regulation. Number 18 of 2012). The processing of waste at low cost, feasible in terms of health and did not bring negative implications for the environment were some of the serious problems that must be faced by the government and must be considered by all elements of society.

The development of epidemiological aspects specifically described the role of the environment in the occurrence of diseases and plague, and the environment affected the occurrence of disease. Human interaction with the environment was a natural and implemented since the human was born until he/she died, this was because humans need the carrying capacity of environmental elements for their survival (Entjang in Hamzah, 2009).

Environmental-based diseases were still a current problem. This was because environmental-based diseases were always included in the top 10 diseases in almost all Community Health Centers in Indonesia. This situation indicated the low coverage and quality of environmental health interventions (Prabu, 2008).

Efforts to prevent and reduce the incidence of diarrhea which was one of the environmental-based diseases, were expected to increase the collaboration of minimal services between the Health Office, the Sanitary Office, and the Environmental office to collaborate in improving environmental health programs related to basic sanitation which were the risk factors for diarrhea especially the household waste management, such as increasing the number and quality of temporary waste can, as well as determining the location of the placement.

Community health center was collaborated with cross-sector partnerships to improve ongoing counseling about clean and healthy living behaviors, improve hand washing with soap in collaboration with other organizations, government and private to increase the percentage of hand washing by using soap.

\section{REFERENCES}

Analisa (2003). Enviromental Services Program www.Esp.DR.id. Coorporate Plan PDAM Tirtanadi Sumut 20062010.

Angeline, Marsaulina, Naria (2012). Hubungan Kondisi Sanitasi Dasar dengan Keluhan KesehatanDiare serta Kualitas Air pada Pengguna Air Sungai Deli di Kelurahan Sukaraja Kecamatan Medan Maimun Tahun 2012.

Departemen Kesehatan RI (2005). Buku Pedomanan Penataksaan Program P2 Diare, Jakarta: Ditjen PPM dan PL.

Dinas Kesehatan Kota Medan (2017). Profil Dinas Kesehatan Kota Medan 2017.

Hamzah, Pratiwi N (2009). Fasilitas Jamban Keluarga Dan Pengelolaan Air Limbah Di Kelurahan Barombong Kecamatan Tamalate Tahun 2009. Karya Tulis Ilmiah, Fakultas Kedokteran Universitas Muslim indonesia (Online) http://www.artikelkedokteran.com/516/fasilitasjamban-keluarga-dan-pengelolaan-air-limbah-dikelurahan-barombongkecamatan-tamalate-tahun-2009.html. Accesed on $19^{\text {th }}$ June 2018.

Mulyani HNS, Kuscithawati S (2011). Faktor Risiko Diare Akut pada Balita, Berita Kedokteran Masyarakat, Jurnal UGM,27(1).

Kementerian Kesehatan RI (2011), Situasi Diare di Indonesia. Jakarta. (2011). Panduan Tata Laksana Diare Balita untuk Petugas Kesehatan Jakarta: Direktorat Jenderal Pengendalian Penyakit dan Penyehatan Lingkungan. 
Journal of Epidemiology and Public Health (2019), 4(1): 47-54

https://doi.org/10.26911/jepublichealth.2019.04.01.06

(2012). Buku Saku Petugas Lintas Diare. Ditjen PPM dan PL, Jakarta. (2015). Millenium Development Goals Indonesia, Depkes RI, Jakarta. (2015). Higiene dan Diare, Kemenkes RI Jakarta.

Madhi SA, Cunliffe NA, Steele D, Witte D, Kirsten M, Louw C, Ngwira B et al., (2010). Effect of Human Rotavirus Vaccine on Severe Diarrhea in African Infants. N Engl J Med, 362: 289-298.

Mulia MR (2005). Kesehatan Lingkungan. Yogyakarta: Graha Ilmu.

Prabu P (2008). Penyakit Berbasis Lingkungan. http://putraprabu.wordpress.com/2008/10/10/penyakit-berbasislingkungan/. Accesed on $15^{\text {th }}$ July 2018.

Profil Dikes Sumatera Utara (2007). Profil Dinas Kesehatan Sumatera Utara.

Sabaraiah (2014). Pengaruh Karakteristik, Sanitasi Dasar, dan Upaya Pencegahan terhadap Kejadian Diare pada Balita (1-<5 tahun) di di Kelurahan Sei Sekambing C II Wilayah Kerja Puskesmas Helvetia Kota Medan, Tahun 2015: Tesis Fakultas Kesehatan Masyarakat, Program S2 Kesehatan Masyarakat Universitas Sumatera Utara.

Guandalini S (2011). Probiotics for Prevention and Treatment of Diarrhea. Journal of Clinical Gastroenterology, 45(2): S149-S153.

Sunarti (2015). Faktor-faktor yang Mempengaruhi Kejadia Diare pada Anak Balita (1-<5 tahun) di Kota Padangsidempuan Tahun 2015: Tesis Fakultas Kesehatan Masyarakat, Program
S2 Kesehatan Masyarakat Universitas Sumatera Utara.

Sugiono (2014). Metode penelitian kuantitatif dan Kualitatif. Bandung: Alfabeta.

Sutomo AH, Machfoed I, Ratna W (2013). Kesehatan Lingkungan Untuk Keperawatan. Yogyakarta: Fitramaya.

Undang-Undang No.18 tahun 2008 tentang Pengelolaan Sampah. Jakarta Pusat.

UNICEF (2009) World Health Organization. Diarhoea. Why children are still dying and what can be done, http://whqlibdoc.who.int/publications/2009/9789241598415 eng.pdf. Accessed on $30^{\text {th }}$ June 2018.

UNICEEF Liberia (2012). Communication Strategy on Water, Sanitation \& Hygiene for Diarrhoea \& Cholera Prevention. www.unicef.org/cbsc/files/Liberia_WASH-Cholera-Diarrhoea_Comms_Strategy_2012/pdf. Accessed on $2^{\text {nd }}$ July 2018.

WHO (2013). Penyakit Diare. (http:/www.scribd.com//doc/47503863/who-diare). Accessed on $20^{\text {th }}$ February 2015. (2013). Diarrhoeal Disease. Http://www.who.int-

/mediacentre/factsheets/fs330/en/index.html. Accessed on $22^{\text {th }}$ June 2018.

WHO Library Cataloguing in Publication Data (2013). World Health Statistics 2013. http://www.who.int/gho/publications/world_health_statistics/fen. Accessed on $2^{\text {nd }}$ July 2018. 